\title{
SIKAP ANAK DENGAN GANGGUAN EMOSI DAN TINGKAH LAKU TERHADAP PERILAKU ASERTIF DI SEKOLAH LUAR BIASA
}

\author{
Shintesa Mayu Fitriya \\ Hartini Nara
}

\begin{abstract}
This research aims to improve speaking skills through watching videos kids children stories of children aged 5-6 years in kindergarten Islam Al-Fattah, Wanasari Village, Bekasi regency. The methodology uses a classroom action research which conduct through two cycle consists of planning, action, observation, and reflection. Subjects are 10 children in group $B$ who have problems with aspects of speech. Data collection techniques use non-test consists of observation, interview, and documentation. The analysis techniques use two paradigms that is mean, medium, modus, proportion study with a minimum percentage increase to $71 \%$ for quantitative paradigm, and data reduction, data display, conclusion/verification for qualitative paradigm.
\end{abstract}

Key words: speaking skills, story VCD, watching children.

Abstrak

Penelitian ini bertujuan untuk mengembangkan kemampuan berbicara anak melalui menonton video cerita anak pada anak usia 5-6 tahun di TK Islam Al-Fattah, Desa Wanasari, Kabupaten Bekasi. Metodologi yang digunakan adalah penelitian tindakan kelas yang dilakukan melalui dua siklus, dan setiap siklusnya terdiri atas perencanaan, tindakan, pengamatan, dan refleksi. Subjek penelitian adalah anak kelompok B sebanyak 10 orang yang mempunyai masalah pada aspek kemampuan berbicara. Teknik pengumpulan data menggunakan nontes melalui teknik observasi, wawancara, dan dokumentasi. Teknik analisis data penelitian menggunakan dua paradigma yaitu paradigma kuantitatif seperti mean, median, modus, dan studi proporsi dengan minimum presentasi kenaikan $71 \%$ dan paradigma kualitatif seperti reduksi data, display data dan verifikasi.

Kata kunci : kemampuan berbicara, VCD cerita, anak menonton

\section{PENDAHULUAN}

Secara hakikat, manusia adalah makhluk sosial karena tidak dapat hidup tanpa bantuan orang lain. Manusia satu sama lain saling membutuhkan. Atas dasar itulah maka terjadi interaksi sosial di antara individu. Interaksi terjalin melalui komunikasi yang melahirkan bermacam perilaku. Perilaku terpuji ditunjukkan dengan rasa hormat dari yang muda kepada orang tua dan kasih sayang dari yang lebih tua kepada anak muda.

Dalam berinteraksi secara sosial banyak faktor yang memunculkan kendala dan berujung pada keretakan hubungan. Salah satunya adalah tindak pemaksaan. Terdapat berbagai kasus tentang pemaksaan kehendak seseorang terhadap orang lain. Tak bisa dipungkiri bahwa pemaksaan acapkali terjadi di kalangan individu yang lebih tinggi-kekuasaan, kedudukan, kekayaan, usia, dan lainnya-kepada individu yang lebih rendah. Khususnya adalah pemaksaan kehendak terhadap anak.

Anak memiliki kecenderungan larut dalam kegiatan dengan teman-teman sebaya. Sesuai dengan karakternya, anak senang untuk mencoba berbagai hal. Keikutsertaan anak dapat membawanya menuju hal yang baik ataupun tidak baik. Adakalanya anak hanya bersikap ikut-ikutan pada suatu kegiatan tanpa alasan kuat. Anak-anak adalah objek yang rentan dengan tekanan dan keinginan teman atau orang di sekitar untuk berperilaku tidak sesuai dengan keinginan pribadi. Anak-anak yang berperilaku demikian sebenarnya mampu untuk melakukan penolakan. Namun anak-anak memilih untuk tidak mau menolak, dengan kata lain tidak mau bertindak secara asertif.

Hal ini dibuktikan dengan penelitian kualitatif 
oleh Novianti (2008). Novianti melaporkan bahwa umumnya remaja enggan berperilaku asertif karena takut dijauhi oleh teman-temannya ataupun demi menghindar dari hukuman yang diberikan oleh orangtuanya. Walau sebenarnya anak-anak mampu bersikap asertif namun dalam penerapannya jarang sekali yang dapat mewujudkan perilaku tersebut. Penelitian Novianti didukung oleh data dari penelitian survey yang dilakukan oleh Rinawati (2009). Pada penelitiannya di SMAN 9 Malang, Rinawati melaporkan bahwa banyak sekali $(81,58 \%)$ siswa yang memiliki perilaku asertif tinggi dan sedikit sekali $(18,42 \%)$ siswa yang memiliki perilaku asertif cukup tinggi. Dari kedua penelitian di atas menyatakan bahwa anak mampu bertindak secara asertif. Akan tetapi, banyak pengaruh yang mengintervensi anak sehingga perilaku tersebut tidak muncul. Kendati demikian perilaku asertif perlu dipelajari sejak dini.

Perilaku asertif tidak hanya butuh dipelajari oleh anak-anak dan remaja yang "normal" dalam perilaku. Namun keterampilan ini perlu dikuasai oleh anak dengan gangguan emosi dan tingkah laku. Anak dengan penyimpangan emosi dan perilaku dikenal dengan anak yang antisosial. Umumnya anak yang antisosial gagal untuk membangun komunikasi maupun menjalin hubungan yang baik dengan pribadi (intrapersonal) dan dengan individu yang lain (interpersonal).

Ketidakmampuan yang ditampilkan dalam membangun komunikasi intrapersonal ditunjukkan dengan rendahnya harga diri (selfesteem), konsep diri, rasa percaya diri (selfconfident), dan bertindak impulsif. Sedangkan kegagalan membangun hubungan interpersonal diwujudkan dengan cenderung berbicara kasar, berintonasi tinggi, mengganggap remeh orang lain, bersikap agresif, maupun terlalu pasif. Dengan penyimpangan perilaku ini maka anakanak tersebut termajinalkan dari lingkungan masyarakat. Tersisihnya anak dari masyarakat disebabkan oleh perilakunya yang tidak sesuai dengan harapan dan norma-norma yang ada.

Hambatan emosi dan perilaku yang dialami anak membuatnya sulit untuk mempelajari berbagai perilaku baik. Kendati di sekolah telah diajarkan bermacam perilaku, norma, dan aturan dalam masyarakat. Harapannya adalah ketika anak mempelajari satu perilaku, maka anak akan dapat mengambil sikap atas perilaku tersebut dengan pertimbangan yang matang. Karena disadari bahwa anak dengan gangguan emosi dan tingkah laku tidak selalu berada dalam lingkungan yang homogen. Namun dapat kembali ke tengah-tengah masyarakat di mana berbagai hubungan berkembang lebih luas.

Salah satunya adalah bersikap terhadap perilaku asertif. Upaya untuk membangun sikap terhadap perilaku asertif merupakan hal yang penting. Hal ini erat kaitannya dengan keberhasilan anak dalam menjalin hubungan intrapersonal maupun interpersonal yang telah disinggung sebelumnya. Ketika perilaku asertif dipelajari secara kontekstual maupun operasional maka dapat menjadi stimulus yang memungkinkan berkembangnya perilaku anak menjadi lebih baik.

Bagi sekolah berasrama seperti Sekolah Luar Biasa bagian E (tunalaras) Handayani, berbagai sikap anak dapat diamati dengan lebih cermat. Alasannya karena di sekolah ini, anak dengan gangguan emosi dan tingkah laku tidak hanya mendapat pengawasan dari guru namun juga oleh pekerja sosial. Di sekolah ini terdapat banyak interaksi yang bersinggungan dengan perilaku asertif, baik di antara anak maupun dengan guru dan masyarakat. Interaksi berupa saling menghormati sesama hingga saling mengintimidasi kerap terjadi.

Peristiwa tersebut merupakan segelintir gambaran sikap anak terhadap perilaku asertif. Sekalipun demikian, berbagai fakta yang ditampilkan belumlah memberikan informasi secara empiris tentang sikap anak. Oleh karena itu, diperlukan penelitian mengenai sikap anak dengan gangguan emosi dan tingkah laku terhadap perilaku asertif di Sekolah Luar Biasa bagian E (SLB-E) Handayani Jakarta Timur.

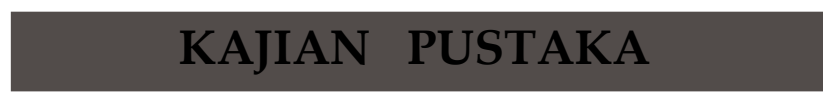

Ahmadi (2002) menyatakan sikap sebagai suatu hal yang menentukan sikap sifat, hakikat, baik perbuatan sekarang maupun perbuatan yang akan datang. Oleh karena itu sikap erat kaitannya dengan reaksi subjek beserta karakter atas reaksi tersebut yang sifatnya menetap. Pengertian ini sejalan dengan pendapat Gerungan (2008) yang menjabarkan sikap sebagai sikap dan kesediaan beraksi terhadap suatu hal. Atau menurut Notoatmodjo dalam Arif (2008), yang menggambarkan sikap sebagai reaksi atau respon yang masih tertutup dari seseorang terhadap suatu stimulasi atau objek, sikap secara nyata menunjukkan konotasi adanya kesesuaian reaksi terhadap stimulus tertentu yang dalam kehidupan sehari-hari, merupakan suatu reaksi yang bersifat emosional terhadap stimulus sosial. Dalam definisi yang dikemukakan Notoatmodjo, sikap belum dinyatakan sebagai respon yang nampak atas berbagai stimulus 
atau rangsangan sosial. Di mana stimulus sosial yang terjadi dapat berupa benda atau orang. Dalam definisi tersebut Notoadmodjo lebih menekankan sikap pada dimensi afek karena reaksi atas stimulus hanya dilihat dari aspek emosional.

Kemudian Thurstone dalam Walgito (1994) mendefinisikan sikap yang merupakan suatu tingkatan afeksi positif atau negatif yang berhubungan dengan objek psikologi. Objek psikologi yang dimaksud Thurstone adalah simbol, frase, slogan, orang, institusi, kesadaran, atau ide, di mana orang dapat menanggapi secara berbeda pada afeksi positif atau negatif. Demikian halnya dengan definisi dari Notoatmodjo, definisi yang dikemukakan Thurstone pun hanya menjelaskan bahwa sikap terlahir dari dimensi afek tanpa menyertakan organisasi aspekaspek psikologis lainnya. Namun demikian, Thrustone telah menyinggung bentuk reaksi dari sikap yang terlahir yakni sikap yang positif dan sikap yang negatif. Hal ini belum disinggung dalam definisidefinisi sebelumnya.

Selain definisi di atas, pemikiran mengenai sikap disampaikan oleh Jung dalam Wikipedia (2009) yakni kesiapan untuk bereaksi atau tidak bereaksi pada jalan tertentu. Dalam definisi ini, Jung menekankan sikap pada kesiapan, antisipasi reaksi pada objek sikap. Definisi ini jauh lebih ringan dari dua definisi sebelumnya. Namun dalam definisi yang dikemukakan Jung sudah menyinggung aspek lain yakni aspek konatif. Aspek konatif merupakan aspek yang berkaitan dengan kesiapan bereaksi dari subjek sikap terhadap objek sikap.

Di samping pendapat para ahli yang telah dikemukakan, beberapa ilmuwan mendefinisikan sikap dengan mengaitkannya pada tiga aspek atau dikenal dengan skema triadik. Menurut Secord \& Backman yang dikutip oleh Azwar (2008), sikap merupakan keteraturan tertentu dalam hal perasaan (afeksi), pemikiran (kognisi), dan predisposisi tindakan (konasi) seseorang terhadap suatu aspek di lingkungan sekitarnya. Pendapat terakhir menyatakan bahwa sikap mengandung tiga komponen pembentuknya. Pertama, komponen afektif (affect), kedua, yaitu konatif (behavior), dan ketiga ialah kognitif (cognition). Dalam perkembangan penelitian mengenai sikap, ketiganya dikenal dengan model ABC. Komponen itu merupakan ranah yang membentuk struktur sikap.

Dengan demikian, maka sikap adalah penilaian yang diwujudkan dengan reaksi atau respon tertentu berupa suka (positif) atau tidak suka (negatif) terhadap objek sikap yang melibatkan organisasi aspek-aspek psikologis yakni kognitif, afektif, dan konatif.
Berbagai variasi istilah dikenal untuk menyebutkan anak yang mengalami penyimpangan emosi dan tingkah laku. Hal ini dikarenakan belum adanya alat ukur yang dapat digunakan, belum ada kesepakatan yang jelas mengenai keadaan kesehatan mental yang baik, berbagai macam teori yang dikemukakan para ahli dan pengaruh kultural serta masalah yang lain (Muljono dan Sujadi, 1994). Dalam perkembangannya di Indonesia anak-anak ini disebut dengan anak tunalaras. Tuna berarti kurang dan laras berarti sesuai. Jadi, tunalaras adalah anak yang bertingkah laku kurang sesuai dengan lingkungan (Ibrahim dan Rohana, 1996). Namun, istilah ini dirasa kurang tepat sehingga diperinci menjadi gangguan emosi dan tingkah laku.

Kaufman dan Hallahan dalam Sunardi (1995) menyatakan bahwa yang dimaksud anak dengan gangguan tingkah laku adalah anak yang secara kronis dan menyolok berinteraksi dengan lingkungannya yang secara sosial tidak dapat diterima dan atau secara pribadi tidak menyenangkan tetapi masih dapat diajar untuk dapat diterima agar berinteraksi secara sosial dan secara pribadi menyenangkan. Dalam masyarakat secara sadar maupun tidak, anak-anak ini ada dan dikenal dengan sebutan anak nakal. Namun jika ditilik kembali relevansi sebutan anak nakal dengan definisi dari Kaufman, dan Hallahan maka anak-anak tersebut masih memiliki haknya untuk diajar menjadi anak yang menurut masyarakat awam tidak nakal.

Sedangkan Bower dalam Kaufman dan Hallahan (1978), menyatakan bahwa gangguan emosi dan tingkah laku adalah anak yang menunjukkan satu atau lebih dari karakteristik di bawah ini selama jangka waktu tertentu: (1) ketidakmampuan untuk belajar di mana hal itu tidak dapat dijelaskan melalui segi intelektual, sensori, atau faktor kesehatan; (2) ketidakmampuan untuk membangun/memelihara hubungan baik yang memuaskan dengan kelompoknya dan guru-gurunya; dan (3) bentuk perilaku atau perasaan yang tidak dapat di bawah kondisi yang normal.

Selanjutnya Mangunsong (1998) menambahkan karakteristik dari anak yang memiliki gangguan emosi dan tingkah laku yaitu umumnya sering menjurus pada perasaan tidak bahagia atau tertekan dan cenderung berkembang simtom-simtom fisik atau dihubungkan dengan ketakutan yang berhubungan dengan masalah pribadi atau sosial. Keseluruhannya merupakan hal yang melekat pada diri anak dengan gangguan emosi dan tingkah laku. Karakteristik ini sejalan dengan pendapat Somantri (2006) yang 
menyatakan bahwa dalam perkembangan kognitif, anak-anak ini cenderung memiliki IQ di bawah ratarata dan dalam aspek sosial dan emosi cenderung berkonflik, baik dengan dirinya maupun lingkungan.

Dari berbagai definisi yang telah dikemukakan di atas maka dapat disimpulkan bahwa yang dimaksud anak dengan gangguan emosi dan tingkah laku adalah anak yang secara menyolok dan kronis berperilaku tidak sesuai dengan lingkungan masyarakat yang dimanifestasikan dengan ketidakmampuan untuk belajar, membangun dan memelihara hubungan interpersonal, cemas berlebihan dan tertekan, serta memperlihatkan simtom fisik berupa fobia terhadap masalah pribadi dan sosial, namun masih bisa diajar untuk dapat berperilaku sesuai dengan norma masyarakat dan menyenangkan secara pribadi.

Horgie dalam Mitra Riset (2008) menyatakan bahwa perilaku asertif merupakan terjemahan dari istilah assertiveness atau assertion yang artinya titik tengah antara perilaku nonasertif dan perilaku agresif. Oleh karena itu, dengan bersikap asertif maka individu tidak akan bersikap menjurus ke arah agresif yaitu perilaku yang secara verbal maupun nonverbal mengintimidasi individu lain maupun ke arah pasif yakni perilaku yang secara verbal maupun nonverbal cenderung menerima intimidasi dari individu lain. Dengan bersikap asertif, maka individu dilatih untuk berdiri di antara sikap agresif maupun sikap pasif.

Kemudian Sukadji dalam Dunia Psikologi (2009) melihat perilaku asertif sebagai perilaku seseorang dalam hubungan antarpribadi yang menyangkut emosi yang tepat jujur, relatif terus terang, dan tanpa perasaan cemas terhadap orang lain. Definisi ini menyatakan bahwa perilaku asertif akan membangun hubungan interpersonal yang baik. Hubungan interpersonal yakni menyangkut hubungan individu dengan sesamanya. Interaksi dalam hubungan yang asertif melibatkan aspek emosi yang tidak berlebihan serta menekankan sikap saling terbuka. Selain itu pula, asertif mendorong individu memiliki pikiran positif terhadap diri sendiri dan orang lain sehingga perilaku yang ditampilkan akan jujur dan tegas.

Senada dengan Sukadji, Cawood (1997) mendefinisikan perilaku asertif sebagai ekspresi yang langsung, jujur, dan pada tempatnya dari pikiran, perasaan, kebutuhan, atau hak-hak individu tanpa kecemasan yang tidak beralasan. Definisi ini menjelaskan bahwa perilaku asertif turut serta menjaga hak-hak pribadi maupun hak orang lain. Hak merupakan sesuatu yang harus dan layak diterima setiap individu. Dengan demikian, karakteristik perilaku asertif termasuk menghormati dan menghargai keberadaan diri sendiri dan orang lain sehingga terbangun sikap saling menghormati yang merupakan fondasi dalam hubungan interpersonal.

Beardsley et al (2008) mendefinisikan perilaku asertif ialah menyatakan secara langsung suatu ide, opini, dan keinginan. Oleh karenanya konsep dari perilaku asertif adalah hubungan timbal balik yang menekankan adanya kejujuran dan komunikasi langsung. Perilaku ini mencerminkan interaksi positif dalam memberi dan menerima. Memberi atau menunjukkan perilaku dengan cara tidak merugikan orang lain serta menerima atau merespon perilaku dengan tidak dirugikan oleh pihak manapun serta interaksi yang ditunjukkan merupakan interaksi yang langsung atau tidak berbelit-belit.

Dari berbagai uraian di atas, maka dapat disimpulkan bahwa yang dimaksud dengan perilaku asertif adalah kemampuan mengekspresikan serta kemampuan menerima pikiran, perasaan, dan keyakinan secara langsung, jujur dan pada tempatnya yang menyangkut hubungan interpersonal tanpa perasaan cemas, serta mampu menjaga dan menghargai hak-hak pribadi maupun hak orang lain.

Boggs dalam Wolverson (2009) mengidentifikasi empat kemampuan dalam berperilaku asertif yaitu dapat mengatakan "tidak", menyatakan kebutuhan, mampu mengekspresikan pikiran dan perasaan secara tepat, dan mampu berinteraksi secara langsung dan berkesinambungan. Sedangkan Bower dan Bower dalam Mitra Riset (2008) mengungkapkan bahwa seseorang yang berperilaku asertif harus memiliki dua belas kemampuan. Pertama adalah kemampuan berbicara dengan perasaan (use feeling talks). Kedua, kemampuan membicarakan tentang dirinya (talks about yourself). Ketiga ialah kemampuan berbicara dengan ramah (make greeting talks). Keempat yaitu kemampuan menerima pujian (accept compliments). Kelima, kemampuan berbicara dengan ekspresi yang tepat (use appropriate facial talks). Keenam, kemampuan menolak dengan lembut (disagree midly). Ketujuh yaitu kemampuan meminta penjelasan (ask for clarification). Kedelapan ialah kemampuan menanyakan alasan (ask why). Kesembilan, kemampuan asertif selanjutnya yaitu kemampuan mengekspresikan ketidaksetujuannya (express active disagreement). Kesepuluh, yakni kemampuan merespon haknya (speak up for the rights). Kesebelas merupakan kemampuan untuk tetap tenang (be persisten). Terakhir adalah kemampuan menghindari pembenaran (avoid justifying every opinion) yakni kemampuan untuk tegas dalam berperilaku. 
Pendapat selanjutnya adalah dari Cawood (1997) yang membagi keterampilan berperilaku asertif menjadi dua yaitu keterampilan memberi dalam perilaku asertif dan keterampilan menerima dalam perilaku asertif. Keterampilan memberi meliputi enam hal yaitu memberikan informasi, memberikan pendapat atau opini, menyatakan kebutuhan dan harapan, berbagi perasaan, memberikan keputusan, dan menyampaikan kritik atau pujian.

Telah disebutkan selain keterampilan memberi juga ada keterampilan menerima dalam perilaku asertif yang mencakup enam perilaku yaitu mencari informasi, merefleksikan isi pesan, merefleksikan perasaan, menerima kritik, menerima pujian, dan meneladani fleksibilitas atau bersikap luwes.

\section{METODOLOGI PENELITIAN}

Tujuan penelitian ini adalah untuk memperoleh gambaran sikap anak dengan gangguan emosi dan tingkah laku terhadap perilaku asertif di Sekolah Luar Biasa Bagian E (SLB-E) Handayani Jakarta Timur. Penelitian dilaksanakan di Sekolah Luar Biasa Bagian E (tunalaras) Handayani, Cipayung, Jakarta Timur. Penelitian dilaksanakan pada bulan Februari 2009 hingga Juni 2010. Metode yang digunakan dalam penelitian ini adalah survei dengan teknik deskriptif. Populasi dalam penelitian ini adalah seluruh anak dengan gangguan emosi dan tingkah laku yang bersekolah di Sekolah Luar Biasa Bagian E (tunalaras) Handayani, Jakarta Timur tingkat sekolah menengah pertama dengan jumlah 44 anak yang duduk di kelas VII hingga IX tingkat sekolah menengah pertama. Sampel penelitian diambil dengan menggunakan teknik total sampling (sampel total/sensus) sehingga sampel dalam penelitian ini berjumlah 44 anak pada tingkat sekolah menengah pertama.

Variabel yang digunakan dalam penelitian ini adalah dengan satu variabel yaitu sikap anak dengan gangguan emosi dan tingkah laku terhadap perilaku asertif di Sekolah Luar Biasa Bagian E (SLB-E) Handayani, Jakarta Timur. Instrumen penelitian yang dikembangkan untuk memperoleh gambaran tentang sikap anak dengan gangguan emosi dan tingkah laku terhadap perilaku asertif di Sekolah Luar Biasa Bagian E (SLB-E) Handayani, Jakarta Timur adalah menggunakan angket skala sikap model Likert. Responden akan menyatakan kesetujuannya atau ketidaksetujuannya dengan alternatif pilihan SS (sangat setuju), S (setuju), R (ragu-ragu), TS (tidak setuju), dan STS (sangat tidak setuju). Rentang skor yang digunakan adalah satu sampai lima. Jika pernyataan positif maka pilihan SS (sangat setuju) memiliki skor 5, S (setuju) memiliki skor 4, R (raguragu) memiliki skor 3, TS (tidak setuju) memiliki skor 2, dan STS (sangat tidak setuju) memiliki skor 1.

Sedangkan untuk pernyataan negatif maka pilihan SS (sangat setuju) memiliki skor $1, \mathrm{~S}$ (setuju) memiliki skor 2, R (ragu-ragu) memiliki skor 3, TS (tidak setuju) memiliki skor 4, dan STS (sangat tidak setuju) memiliki skor 5. Untuk penyusunan instrumen penelitian adalah melalui beberapa tahapan yaitu menentukan definisi konseptual dan operasional, menyusun kisi-kisi berdasarkan acuan teori yang berisi variabel, dimensi, dan indikator.

Definisi konseptual variabel yaitu sikap anak adalah penilaian berupa respon menerima atau menolak terhadap perilaku asertif. Definisi operasional variabel adalah sikap anak adalah skor yang diperoleh dari anak setelah mengisi instrumen penelitian dengan menerima atau menolak perilaku asertif yaitu memberikan keputusan; pengungkapan diri; mengemukakan harapan, pikiran, dan kebutuhan; mencari informasi; membangun hubungan (interaksi); serta berbagi perasaan yang meliputi penilaian kognitif, afektif, dan konatif.

Instrumen sikap anak dengan gangguan emosi dan tingkah laku terhadap perilaku asertif disusun menggunakan validitas konstruk atau validitas bangun yang berdasarkan pada kerangka teoretis. Sebelum instrumen digunakan untuk penelitian, diujicobakan dahulu terhadap 17 siswa SMP istimewa di Lembaga Pemasyarakatan Anak Pria Tangerang.

Pengujian reliabilitas untuk mengetahui ketetapan tes sebagai instrumen penelitian maka digunakan rumus Alpa Cronbach. Berdasarkan hasil perhitungan diperoleh hasil $r_{11}=0,970$. Dengan demikian, instrumen ini memiliki reliabilitas yang sangat tinggi sehingga layak digunakan dan memenuhi syarat untuk mengumpulkan data dalam penelitian ini.

Berdasarkan hasil uji coba instrumen baik validitas dan reliabilitas diperoleh instrumen yang valid sebanyak 35 butir dengan koefisien reliabilitas instrumen sebesar 0, 970. Setelah diketahui sebanyak 35 butir pernyataan valid, kemudian dirujuk kembali ke dalam tiap aspek, maka pada aspek kognitif diperoleh 8 butir instrumen valid. Pada aspek afektif sebanyak 10 butir instrumen valid dan sedangkan aspek konatif sebanyak 17 butir instrumen valid. Kemudian guna keseimbangan butir instrumen pada penelitian, 5 butir yang paling rendah pada aspek konatif digugurkan sehingga didapat 12 butir instrumen pada aspek konatif. Dengan demikian, butir 
yang digunakan untuk penelitian ini adalah sebanyak 30, maka secara teori, skor maksimal yang dapat diperoleh adalah 150 dan skor minimal 30.

Data yang terkumpul kemudian diteliti dan diperiksa apakah semua pertanyaan sudah dijawab untuk mengetahui kelengkapan jawaban. Setelah data diperiksa kemudian dianalisis dengan menggunakan analisis statistik deskriptif baik yang berkenaan dengan persentase maupun penggunaan diagram meliputi penyajian data dalam bentuk tabel, histogram, perhitungan modus, median, dan standar deviasi secara keseluruhan maupun tiap kelas. Sikap siswa dikatakan positif apabila skor sikap siswa > skor rata-rata ideal, sedangkan dikatakan negatif apabila skor sikap siswa < skor rata-rata ideal.

\section{HASIL DAN PEMBAHASAN}

Berdasarkan analisis data, hasil penelitian mengenai sikap anak dengan gangguan emosi dan tingkah laku terhadap perilaku asertif, diperoleh hasil sebagai berikut.

Tabel 1. Hasil Penelitian Secara Keseluruhan Responden

\begin{tabular}{|l|c|}
\hline \multicolumn{1}{|c|}{ Statistik Dasar } & Data Keseluruhan \\
\hline Rata-rata & 105.8 \\
\hline Standar Deviasi & 95.9 \\
\hline Median & 106.6 \\
\hline Modus & 106 dan 108 \\
\hline Skor Maksimum & 138 \\
\hline Skor Minimun & 88 \\
\hline
\end{tabular}

Dari seluruh responden diketahui nilai rata-rata sebesar 105,8 atau $70,5 \%$. Setelah hasil diperoleh, ditentukan nilai rata-rata ideal atau batas lulus ideal yaitu 81,25 . Dengan demikian, maka perolehan ratarata responden keseluruhan yaitu 105,8 lebih besar dari rata-rata ideal sebesar 81,25 . Berdasarkan data tersebut dapat disimpulkan bahwa semua responden menunjukkan sikap positif terhadap perilaku asertif.

Tabel 2. Jawaban Responden Berdasarkan Aspek Sikap

\begin{tabular}{|l|l|l|c|l|}
\hline No. & Aspek & Jumlah & $\begin{array}{c}\text { Rata- } \\
\text { rata }\end{array}$ & Prosentase \\
\hline 1. & Kognitif & 1234 & 155,38 & $34 \%$ \\
\hline 2. & Afektif & 1538 & 153,80 & $33 \%$ \\
\hline 3. & Konatif & 1847 & 153,92 & $33 \%$ \\
\hline & jumlah & 4628 & 100,00 & $100 \%$ \\
\hline
\end{tabular}

Selanjutnya, kontribusi jawaban responden pada tiap komponen sikap. Berdasarkan jawaban dari seluruh responden yang berjumlah 44 anak pada tiap komponen sikap yang terdiri dari kognitif, afektif, dan konatif maka didapat skor rata-rata tertinggi yaitu pada aspek kognitif. Kemudian tertinggi kedua adalah aspek konatif dan terakhir adalah aspek afektif.

Berdasarkan data dari keseluruhan responden yaitu sebesar 44 anak dengan 30 pernyataan, diperoleh nilai tertinggi sebesar 138 atau $92 \%$ dari skor maksimal yaitu 150 adalah responden nomor 44 . Nilai tertinggi ini hanya berselisih 12 poin dari skor maksimal. Perolehan skor sebesar 138 menunjukkan indikasi yang sangat baik karena meskipun anak-anak ini mengalami penyimpangan dalam emosi dan tingkah lakunya, namun masih dapat memihak pada perilaku asertif. Kemudian skor tertinggi tersebut juga ditunjang oleh nilai terendah sebesar 88 atau 58,7\% dari skor minimal 30 yaitu responden nomor 37 yang tidak terlalu rendah. Bahkan berselisih cukup jauh dari skor minimal yaitu 58 poin.

Dari seluruh responden diketahui nilai rata-rata sebesar 105,8 atau 70,5\%. Persentase ini cukup tinggi dengan skala perbandingan hingga $100 \%$. Setelah hasil diperoleh, ditentukan nilai rata-rata ideal atau batas lulus ideal yaitu 81,25. Dengan demikian, maka perolehan rata-rata responden keseluruhan yaitu 105,8 lebih besar dari rata-rata ideal sebesar 81,25. Berdasarkan data tersebut dapat disimpulkan bahwa semua responden menunjukkan sikap positif terhadap perilaku asertif. Hal ini berarti seluruh responden mendukung, menyukai, atau menerima perilaku asertif. Dengan kata lain, tidak ada responden yang bersikap negatif terhadap perilaku asertif.

Perolehan rata-rata sebesar 105,8 dibandingkan dengan batas lulus ideal sebesar 81,25 memang tidak terpaut jauh. Selisih dari keduanya diperoleh 24,55 poin atau masih berada dalam kategori rendah. Keadaan ini dipengaruhi oleh kondisi dari dalam dan luar diri anak. Kondisi dari dalam sudah tentu karena anak mengalami masalah dan hambatan dalam hal emosi dan tingkah laku. Keadaan ini merupakan manifestasi dari karakteristik anak yaitu sulit mengendalikan diri, tidak matang, maupun mengalami kelainan kepribadian.

Selanjutnya, kondisi dari luar anak antara lain adalah informasi yang didapat ataupun interaksi yang selama ini dijalani oleh anak. Seringkali informasi yang didapat keliru karena karakteristik anak yang cenderung menutup diri dari apapun termasuk dari berbagai informasi yang disampaikan padanya. 
Serupa dengan cara berinteraksi, anak dengan gangguan emosi dan tingkah laku menunjukkan cara bersosialisasi yang berkelompok ataupun menyendiri. Dengan interaksi yang terbatas, maka sangat mempengaruhi cara anak dalam bersikap terhadap objek sikap.

Pada hasil penelitian menunjukkan bahwa anak dengan gangguan emosi dan tingkah laku bersikap positif terhadap perilaku asertif. Meskipun perolehan skor rata-rata tidak terpaut jauh dari batas lulus ideal. Kenyataan ini mencerminkan bahwa dalam diri anak masih menyukai ataupun mendukung perilaku asertif. Di mana komponen pembentuk perilaku ini tidak hanya perkataan yang langsung, jujur, dan tepat, namun juga dibentuk oleh intonasi bicara, mimik muka, maupun ekspresi tubuh yang selaras dengan perkataan.

Dengan demikian, terdapat kaitan antara karakteristik anak dan perilaku asertif. Hubungannya antara lain adalah walaupun anak suka berbohong namun sebenarnya menyukai kejujuran dan diperlakukan secara jujur. Meskipun anak bertindak impulsif dan agresif akan tetapi mendukung perlakuan yang bersahabat serta ekspresi wajah yang ramah. Penerimaan anak terhadap perilaku asertif diharapkan berimplikasi pada kehidupan sehari-hari misalnya anak dapat menolak dengan tegas ajakan untuk mencoba merokok, meminum minuman keras, ataupun tawuran hingga narkoba. Membatasi dominasi kakak kelas maupun orang lain terhadap dirinya dengan berkata secara jujur. Positifnya sikap anak dengan gangguan emosi dan tingkah laku terhadap perilaku asertif menyumbang fakta bahwa memang anak masih mau dan dapat dididik untuk dapat berperilaku sesuai dengan norma masyarakat dan menyenangkan secara pribadi.

Kemudian kontribusi jawaban responden pada tiap komponen sikap. Berdasarkan jawaban dari seluruh responden yang berjumlah 44 anak, pada tiap komponen sikap yang terdiri dari kognitif, afektif, dan konatif maka didapat skor rata-rata tertinggi yaitu 155,83 atau sebesar 33,55\% pada aspek kognitif. Kemudian tertinggi kedua adalah aspek konatif sebesar 153,92 atau 33,24\% dan terakhir adalah aspek afektif sebesar 153,80 atau 33,21\%. Meski selisih rata-rata pada setiap aspek sangat tipis namun aspek kognitif tetap menduduki peringkat tertinggi. Dari perolehan data tersebut, maka dapat disimpulkan bahwa aspek yang cenderung mempengaruhi anak dengan gangguan emosi dan tingkah laku terhadap perilaku asertif adalah aspek kognitif.

Lahirnya sikap merupakan pengorganisasian antar aspek-aspek sikap. Namun demikian, ada aspek yang lebih berpengaruh ketika anak dengan gangguan emosi dan tingkah laku bersikap terhadap perilaku asertif. Hal ini ditunjukkan dari perolehan skor tertinggi. Dalam penelitian ini diketahui bahwa kecenderungan anak bersikap adalah berdasarkan aspek kognitif tentunya dengan tidak mengabaikan aspek lain. Hal ini berarti kepercayaan, keyakinan, ide, dan konsep anak terhadap perilaku asertif lebih mempengaruhinya dalam bersikap. Dengan kata lain, anak-anak ini lebih mengedepankan logika dalam menyikapi objek sikap dibanding dengan perasaan atau kecenderungan perilaku.

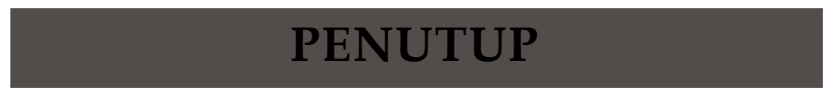

Anak dengan gangguan emosi dan tingkah laku memberikan respon positif terhadap perilaku asertif. Hal ini menunjukkan bahwa dengan bersikap mendukung perilaku asertif, maka subjek paham bahwa setiap orang termasuk dirinya memiliki hak untuk dihargai.

Sikap positif anak menyatakan bahwa meskipun anak memiliki penyimpangan tingkah laku dan hambatan emosi dalam diri, pada dasarnya anakanak ini mendukung, menyukai, memihak pada perilaku yang tegas, jujur, serta saling menghormati hak pribadi yang dikenal dengan perilaku asertif. Sedangkan sikap negatif terhadap perilaku asertif tidak ditunjukkan sama sekali. Dengan memihak pada perilaku asertif membuka peluang bagi anak untuk membangun hubungan yang sehat dengan lingkungan sekitar. Kemudian terdapat kecenderungan lebih tinggi pada salah satu aspek sikap yaitu aspek kognitif. Kenyataan ini menggambarkan bahwa anak dengan gangguan emosi dan tingkah laku mengutamakan logika dalam menyikapi objek sikap.

Terkait dengan hasil yang diperoleh dari penelitian ini maka bagi anak dengan gangguan emosi dan tingkah laku disarankan untuk berlatih sejak dini untuk bersikap jujur, terbuka, namun tegas, dan menghormati hak pribadi dan orang lain. Latihan perilaku asertif dapat dilakukan dengan teman sebaya di keseharian atau dengan guru pada pelajaran bina pribadi dan sosial serta secara khusus dengan psikolog. Dengan keterampilan bersikap asertif maka anak mampu menolak dengan tegas berbagai ajakan negatif seperti mencuri, merokok, maupun mengonsumsi narkoba. Selain itu juga, dapat terhindar dari intimidasi dan dominasi kakak kelas maupun orang lain terhadap dirinya karena anak mampu bersikap secara asertif. 


\section{DAFTAR PUSTAKA}

Ahmadi, A. (2002) Psikologi sosial. Jakarta: Rineka Cipta.

Arif, H. (2008). Sikap (Attitude). Diakses pada tanggal 15 Desember 2008 dari http:// ajangberkarya.wordpress.com

Azwar, S. (2008). Sikap manusia: Teori dan pengukurannya. Yogyakarta: Pustaka Pelajar.

Beardsley, et al (2008) Keterampilan komunikasi pada praktek farmasi. (Mohamad Rusdi Hidayat \& D. Lyrawati, penterjemah). Diakses pada tanggal 15 Desember 2008 dari http://lyrawati.files.wordpress.com/2008/07/wawancaradan-penilaian.pdf

Cawood, D. (1997). Manajer yang asertif. (Hidayat, penterjemah). Jakarta: Gramedia Pustaka Utama

Dunia Psikologi. (2009). Pengertian perilaku asertif. Diakses pada tanggal 12 Januari 2009 dari http://www.duniapsikologi.com

Gerungan, W A. (1996). Psikologi sosial. Bandung: ERESCO.

Ibrahim, N. \& Rohana, A. (1996). Etiologi dan terapi anak tunalaras. Jakarta: Departemen Pendidikan dan Kebudayaan.

Kauffman, J. M. \& Hallahan, D. P. (1978). Exceptional children: Introduction to special education. New Jersey: Prentice-Hall, Inc.

Mangunsong, F. (1998). Psikologi anak luar biasa. Depok: LPSP3.

Mitra Riset. (2008). Asertivitas. Diakses pada tanggal 24 Desember 2008 dari http://www.mitrariset.blogspot.com/200//10/asertivitas.html

Muljono, A. \& Sujadi, S. (1994). Pendidikan luar biasa umum. Jakarta: Departemen Pendidikan dan Kebudayaan.
Novianti, M. C. (2008). Perilaku asertifpada remaja awal. Diakses pada tanggal 24 Desember 2008 dari . http://www. library.gunadarma.ac.id

Rinawati, D. (2009). Hubungan konsep diri dan perilaku asertif dengan kenakalan remaja di SMA N 9 Malang. Diakses pada tanggal 12 Januari dari http:// www.karya-ilmiah.um.ac/index.php

Somantri, T. S. (2006). Psikologi anak luar biasa. Bandung: Refika Aditam.

Sunardi. (1995). Ortopedagogik anak tunalaras I. Jakarta: Departemen Pendidikan dan Kebudayaan.

Walgito, B. (1994). Psikologi sosial: Suatu pengantar. Yogyakarta: Andi.

Wikipedia. (2009) Attitude (Psychology). Diakses pada tanggal 24 Januari 2009 dari http:// en.wikipedia.org/wiki/Attitude(psychology)

Wolverson, C. (2009). Assertiveness in the workplace. Diakses pada tanggal 20 Oktober 2009 dari http://www.naidex.co.uk/page.efm

Zulkaida, A. (2005). Tingkah laku asertif pada mahasiswa. Diakses pada tanggal 15 Desember 2008 dari http://www. Gview.htm

\section{KETERANGAN PENULIS}

Shintesa Mayu Fitriya adalah alumni Mahasiswa Program Sarjana Jurusan Pendidikan Luar Biasa Fakultas Ilmu Pendidikan Universitas Negeri Jakarta Hartini Nara lahir pada tanggal 17 November 1973. Saat ini aktif menjabat sebagai dosen jurusan Pendidikan Luar Biasa Fakultas Ilmu Pendidikan Universitas Negeri Jakarta. 